\title{
TELAAH KANDUNGAN ASAM LEMAK ESENSIAL DALAM EMPAT JENIS MINYAK IKAN KONSUMSI DI JAWA BARAT
}

\author{
Indra Topik Maulana*, Rizka Wulan Sari, Rinda Sri Partina, Isnaeni Nur Azizah \\ Prodi Farmasi,Fakultas Matematika dan IPA, Universitas Islam Bandung, Jl. Rangga gading No. 8 Bandung \\ Jawa Barat 40116, Hp. 081320786909 \\ *email: indra.topik@gmail.com
}

\begin{abstract}
ABSTRAK
Penelitian terkait telaah kandungan asam lemak esensial dari empat jenis minyak ikan konsumsi di Jawa Barat telah selesai dilakukan. Penelitian ini bertujuan untuk memperoleh data ilmiah terkait kandungan asam lemak esensial didalam empat jenis ikan konsumsi. Bahan ikan yang digunakan adalah ikan mujair (Oreochromis mossambicus), ikan nila (Oreochromis niloticus), ikan gurami (Osphronemus goramy), dan ikan Bandeng (Chanos chanos). Minyak dari setiap jenis ikan diekstraksi dengan metode ekstraksi sinambung. Selanjutnya minyak ditransesterifikasi menjadi Fatty Acid Methyl Ester (FAME) kemudian dianalisis dengan menggunakan Kromatografi Gas-Spektroskopi Massa. Data hasil penelitian menunjukkan ikan mujair memiliki rendemen paling tinggi yaitu 8,57 $\pm 0,06 \%$ dari total bahan kering tanpa kepala dan ekor. Ikan nila mengandung minyak paling rendah yaitu 0,28 $\pm 0,09 \%$. Berdasarkan penggolongan asam lemak, Minyak ikan mujaer mengandung Saturated Fatty Acid (SFA) $35,36 \pm 4,86 \%$, MUFA $31,55 \pm 1,79 \%$, PUFA $19,15 \pm 2,05 \%$. Minyak ikan bandeng mengandung SFA 38,12 \pm 4,86 \%, Monounsaturated Fatty Acid (MUFA) 36,64 $\pm 2,21 \%$ dan Poly Unsaturated Fatty Acid (PUFA) 18,4 $\pm 2,02 \%$. Minyak Ikan gurami mengandung SFA $41,65 \pm 2,35 \%$, MUFA 40,29 $\pm 1,13 \%$. Minyak Ikan Nila mengandung SFA 34,11 $\pm 1,73 \%$, MUFA $27,47 \pm 2,11 \%$, dan PUFA $38,43 \pm 2,81 \%$. Asam lemak esensial utama yang ditemukan pada penelitian ini diantaranya adalah Arachidonic Acid (ARA)( $\omega-6)$, Eicosa Pentanoic Acid (EPA)( $\omega-3)$, dan Docosahexanoic Acid (DHA)( $\omega-6)$.
\end{abstract}

Kata kunci: Asam lemak esensial, EPA, DHA, ARA

\begin{abstract}
Research about the study of essential fatty acid content from four types of food fish oil in West Java has been done. The purpose of this research was to obtain scientific data about the content of essential fatty acid in four types of food fish oil. The material that were used in this research were Oreochromis mossambicus, Oreochromis niloticus, Osphronemus goramy, and Chanos chanos. Fish oil from the material were extracted with continuous extraction method. The fish oils were then transesterified become Fatty Acid Methyl Ester (FAME) then be analyzed with Gas Chromatography-Mass Spectroscopy. Data of analysis showed that Oreochromis mossambicus containing highest yield from the other, that was $8,57 \pm 0,06 \%$ of the total weight dried without the head and the tail. Oreochromis niloticus containing lowest yield that was 0,28 $\pm 0,09 \%$. Based on the classification of the fatty acid, the fish oil of Oreochromis mossambicus contained SFA 35,36 \pm 4,86 \%, MUFA 31,55 $\pm 1,79 \%$, and PUFA 19,15 $\pm 2,05 \%$. fish oil of Chanos chanos contained SFA 38,12 $\pm 4,86 \%$, MUFA 36,64 $\pm 2,21 \%$ and PUFA 18,4 $\pm 2,02$ $\%$. Osphronemus goramy contained SFA 41,65 $\pm 2,35 \%$, MUFA 40,29 $\pm 1,13 \%$. Oreochromis niloticus contained SFA $34,11 \pm 1,73 \%$, MUFA $27,47 \pm 2,11 \%$, and PUFA $38,43 \pm 2,81 \%$. The main essential fatty acid that found from this research were $\operatorname{ARA}(\omega-6), \operatorname{EPA}(\omega-3)$, and $\operatorname{DHA}(\omega-6)$.
\end{abstract}

Keywords: Essential fatty acid, EPA, DHA, ARA 


\section{PENDAHULUAN}

Indonesia merupakan wilayah yang memiliki beragam jenis spesies ikan. Diperkirakan di Indonesia hidup sekitar 4000 spesies ikan dengan proporsi $10 \%$ hidup di air tawar dan payau dan $90 \%$ di laut (Genisa, 2003). Jawa Barat merupakan salah satu provinsi yang mengalami peningkatan produksi ikan hasil penangkapan dan budidaya yaitu sebesar 57,72\% (BPS Jabar, 2016). Beberapa ikan yang sering dikonsumsi oleh masyarakat di Jawa Barat diantaranya adalah ikan mujair (Oreochromis mossambicus), ikan nila (Oreochromis niloticus), ikan gurami (Osphronemus goramy), dan ikan Bandeng (Chanos chanos).

Ikan merupakan pangan yang sangat kaya akan asam lemak esensial terutama omega-3 dan omega-6 (Homayooni et all, 2014). asam lemak esensial adalah asam lemak yang sangat dibutuhkan oleh tubuh manusia namun tidak diproduksi secara langsung didalam tubuh. Kandungan asam lemak esensial didalam ikan sangat dipengaruhi oleh cara hidup, jenis makanan, serta karakteristik metabolisme didalam tubuhnya. Ikan yang hidup di alam liar ditambah pada wilayah terdampak polusi akan berbeda karakteristik nutrisinya dengan ikan yang hidup di tempat budidaya (Hussain et al, 2014).

Beberapa contoh asam lemak esensial yang dibutuhkan oleh tubuh diantaranya adalah asam palmitoleat, asam laurat, EPA, DHA, ARA, ALA, dan LA. Asam palmitoleat diketahui dapat mempercepat dalam penyembuhan luka (Weimann et al, 2018). Asam laurat diketahui aktif sebagai antibakteri terhadap Staphylococcus aureus (Tangwatcharin and Khopaibool, 2012). EPA pada penelitian terakhir memiliki potensi sebagai antioksidan dan cardioprotective (Leger et al., 2019).

Uji klinis kombinasi EPA dan DHA terhadap pasien penderita penyakit jantung koroner menunjukkan adanya penurunan angka kematian mendadak sebesar $45 \%$ pada pasien yang mengkonsumsi EPA dan DHA dibandingkan dengan yang tidak mengkonsumsinya (Haris, 2004). EPA dan DHA juga bermanfaat pada terapi keloid (Olaitan et al., 2011), meningkatkan rasio HDL/LDL, antiagregasi platelet, anti inflamasi, dan menurunkan kolesterol dalam darah (Haris, 2004). Suku eskimo berdasarkan penelitian diketahui terbiasa mengkonsumsi ikan yang kaya akan omega3 dibandingkan dengan ras lain. Hal ini ternyata menjadikan penduduk ras eskimo paling sedikit mengalami kematian mendadak akibat penyakit jantung koroner dibandingkan dengan ras lainnya di dunia (Hanafiah et al., 2007). Omega-3 juga berdasarkan hasil penelitian mampu meningkatkan jumlah antioksidan alami seperti superoxide dismutase (SOD) dan glutation peroksidase (GSH px) sehingga 
dapat meredam stress oxidative pada pasien hemodialisis (Khosroshahi et al., 2010). Penelitian lain menyimpulkan bahwa EPA yang dikombinasikan dengan tokoferol mampu menurunkan tingkat lipid peroksidase (Saito and Kubo, 2003).

Adanya kandungan asam lemak bermanfaat dalam ikan konsumsi dapat berpotensi menjadikan ikan konsumsi sebagai sumber minyak ikan kaya akan asam lemak esensial. Penelitian terhadap lima jenis minyak ikan yang beredar di Indonesia, diketahui sebagian besar minyak ikan yang diproduksi di Indonesia tersebut ternyata bersumber dari ikan hiu yang dilindungi. Hal ini terlihat dengan adanya kandungan squalena yang dominan dalam minyak ikan tersebut (Maulana dkk, 2014).

Penelitian ini bertujuan untuk menghasilkan data ilmiah terkait profil kandungan asam lemak yang terdapat didalam empat jenis ikan konsumsi di Indonesia. Manfaat dari penelitian ini adalah dengan diketahuinya kandungan asam lemak didalam setiap jenis ikan, maka kedepan dapat dipilih jenis - jenis ikan yang potensial dijadikan sebagai sumber asam lemak bermanfaat.

\section{METODE PENELITIAN}

\subsection{Alat dan Bahan}

Bahan yang digunakan pada penelitian ini diantaranya adalah ikan mujair ( $O$. mossambicus), ikan nila (O. niloticus), ikan gurami (O. goramy), dan ikan Bandeng ( $C$. chanos), nheksana (Merck), Metanol (Merck), $\mathrm{BF}_{3}$ (Sigma Aldrich), $\mathrm{NaOH}$ (Merck), $\mathrm{NaCl}$, fenolptalein. Sedangkan alat yang digunakan adalah Erlenmayer (pyrex), gelas kimia (pyrex), buret (pyrex), Seperangkat alat soxhlet (Iwaki), timbangan analitik, penangas dengan pengatur temperatur, penguap vakum putar (bucci), corong Buchner dan vakum, sentrifuga, GCMS Shimadzu QP 2010 ULTRA dengan detektor FID, Kolom DB-5.625.

\subsection{Metode Penelitian}

Penelitian ini dilakukan di Laboratorium Farmasi UNISBA sedangkan determinasi bahan di Museum Zoologi SITH ITB. Penelitian dibagi menjadi tiga tahap yaitu pengolahan bahan, isolasi minyak dari bahan, dan analisis kandungan asam lemak dalam minyak menggunakan instrumen KGSM.

Ikan gurami dan ikan nila yang digunakan pada penelitian ini diambil dari wilayah Tasikmalaya, ikan bandeng diambil dari pasar tradisional di Bandung, Jawa Barat sedangkan ikan mujair diambil dari lokasi budidaya ikan di Subang Jawa Barat.

Setiap bahan diolah dengan cara dicuci, difilet dan dipotong kemudian dikeringkan pada lemari pengering dengan suhu terkontrol. Bahan kering selanjutnya diekstraksi dengan alat soxhlet dengan pelarut nheksana pada suhu $60{ }^{\circ} \mathrm{C}$. Ekstrak nheksana selanjutnya dievaporasi menggunakan rotary evaporator dengan 
suhu $40{ }^{\mathrm{O}} \mathrm{C}$ dan kecepatan rotasi $55 \mathrm{rpm}$ hingga diperoleh cairan berupa minyak berwarna kuning jernih dan berbau khas minyak ikan. Terhadap minyak terlebih dahulu diselanjutnya dianalisis mutunya berupa angka asam dan angka peroksida, untuk selanjutnya dimurnikan melalui tahapan yang dilakukan oleh Maulana (2014).

Minyak ikan murni selanjutnya ditransesterifikasi dengan metode yang sama dengan yang dilakukan oleh Maulana (2014) hingga dihasilkan FAME. FAME yang terbentuk selanjutnya disuntikan kedalam instrumen KGSM dengan sistem kromatografi sebagai berikut : pengaturan suhu injektor $280{ }^{\circ} \mathrm{C}$, Suhu Detektor $240{ }^{\circ} \mathrm{C}$, dan sistem pemanasan oven awal $50{ }^{\circ} \mathrm{C}$ (ditahan 2 menit), dinaikan dengan kecepatan $4{ }^{\mathrm{O}} \mathrm{C} /$ menit hingga $240{ }^{\mathrm{O}} \mathrm{C}$ (ditahan 2 menit). Jadi total waktu analisis KGSM untuk setiap sampel adalah 52 menit. Data yang dihasilkan selanjutnya diolah dan dianalisis terkait kandungan asam lemak berdasarkan hasil pembacaan instrumen GCMS, setiap asam lemak digolongkan berdasarkan kelompok saturasinya, kemudian dibandingkan secara deskriptif.

\section{HASIL DAN PEMBAHASAN}

\subsection{Rendemen Minyak dan Kandungan} Asam Lemak

Tabel 1. Rendemen Minyak Ikan yang Dihasilkan Dari Setiap Jenis Ikan

\begin{tabular}{clcc}
\hline No & \multicolumn{1}{c}{ Jenis Bahan } & Rendemen $(\%)$ & BJ \\
\hline $\mathbf{1}$ & Ikan Mujaer $($ O. mossambicus $)$ & $8,57 \pm 0,06$ & $0,909 \pm 0,011$ \\
\hline $\mathbf{2}$ & Ikan Bandeng $($ C. chanos $\mathrm{F})$ & $6,73 \pm 0,71$ & $0,871 \pm 0,009$ \\
\hline $\mathbf{3}$ & Ikan Gurami $($ O. goramy Lacépède $)$ & $1,51 \pm 0,33$ & $0,719 \pm 0,012$ \\
\hline $\mathbf{4}$ & Ikan Nila $($ O. niloticus L. $)$ & $0,28 \pm 0,09$ & $0,717 \pm 0,018$ \\
\hline
\end{tabular}

Ket: Rendemen dihitung terhadap bobot bahan kering tanpa kepala dan ekor ikan

Empat jenis ikan yang dijadikan bahan uji, meskipun sama - sama hidup di air tawar, namun ternyata memiliki kandungan minyak lemak yang berbeda beda seperti yang tampak pada tabel 1 . Rendemen tertinggi diperoleh dari sumber ikan mujaer yaitu sebesar 8,57\% (b/b). Sedangkan ikan nila menghasilkan jumlah minyak paling rendah yaitu sebesar $0,28 \%$. Ikan mujaer dan ikan nila seperti diketahui memiliki kelas yang sama yaitu Oreochromis. Namun meskipun begitu, kandungan minyak lemak pada kedua ikan tersebut jauh berbeda. Hal ini kemungkinan disebabkan karena sumber nutrisi kedua spesies yang berbeda. Menurut Haris (2004) kandungan omega-3 didalam ikan sebenarnya berasal dari plankton atau alga yang dikonsumsi oleh ikan tersebut. Hal ini memperlihatkan bahwa setiap ikan meskipun berada pada lokasi hidup yang sama, kelas taksonomi yang juga sama, namun tetap memiliki karakteristik minyak lemak yang berbeda. 
Telaah Kandungan Asam Lemak Esensial...

Ikan mujaer diketahui menghasilkan rendemen minyak yang paling banyak. Data kandungan asam lemak dalam empat jenis minyak ikan (tabel 2) memperlihatkan bahwa hanya ikan mujaer dan ikan bandeng yang memiliki EPA dan DHA. Asam heksadekanoat (asam palmitat) dan asam 9oktadesenoat (asam oleat) merupakan dua jenis asam lemak yang paling sering ditemukan pada keempat minyak ikan.

Kedua asam lemak tersebut proporsinya paling dominan pada seluruh minyak dibandingkan jenis asam lemak lainnya. Hal tersebut erat kaitannya dengan peran enzim desaturase pada ikan yang dapat mengubah asam lemak jenuh menjadi tak jenuh namun terbatas hanya mampu menghasilkan jenis MUFA omega-9 saja (Bockisch, 1998). Oleh karena itu sangat wajar, kandungan asam oleat dalam ikan sangat besar dibandingkan PUFA (Bockisch, 1998). Asam palmitat sendiri merupakan bahan dasar pembentukan MUFA dan PUFA, sehingga kandungan asam palmitat sangat dominan pada seluruh jenis minyak ikan.

Tabel 2. Profil asam lemak dari tiga jenis minyak ikan air tawar

\begin{tabular}{|c|c|c|c|c|c|c|}
\hline No & $\begin{array}{l}\text { Tingkat } \\
\text { Saturasi }\end{array}$ & nama ilmiah & $\begin{array}{c}\text { Ikan } \\
\text { Mujair } \\
(O . \\
\text { mossambic } \\
\text { us }) \\
(\%) \\
\end{array}$ & $\begin{array}{c}\text { Ikan } \\
\text { Bandeng } \\
(C . \\
\text { chanos } \\
\text { F) } \\
(\%) \\
\end{array}$ & $\begin{array}{c}\text { Ikan Gurame ( } O \text {. } \\
\text { goramy Lacépède) } \\
(\%)\end{array}$ & $\begin{array}{c}\text { Ikan } \\
\text { nila } \\
(O . \\
\text { niloticu } \\
\text { s) } \\
(\%) \\
\end{array}$ \\
\hline 1 & MUFA & Asam 9-Heksadesenoat & $\begin{array}{c}11,98 \pm \\
0,54\end{array}$ & $\begin{array}{c}3,91 \pm \\
0,35\end{array}$ & 0 & 0 \\
\hline 2 & MUFA & $\begin{array}{l}\text { asam Cis 10- } \\
\text { Heptadesenoat }\end{array}$ & 0 & $\begin{array}{c}1,09+ \\
0,18 \\
\end{array}$ & 0 & 0 \\
\hline 3 & MUFA & Asam 11-oktadesenoat & 0 & $\begin{array}{c}6,31 \pm \\
0,11\end{array}$ & 0 & 0 \\
\hline 4 & MUFA & Asam 9-Oktadesenoat & $\begin{array}{c}19,57 \pm \\
2,33\end{array}$ & $\begin{array}{c}23,8 \pm \\
1,41\end{array}$ & $40,29 \pm 1,13$ & $\begin{array}{c}27,47 \pm \\
2,11\end{array}$ \\
\hline 5 & MUFA & Asam cis-11-Eikosanoat & 0 & $\begin{array}{c}1,55 \pm \\
0,16\end{array}$ & 0 & 0 \\
\hline 6 & PUFA & $\begin{array}{l}\text { Asam 9,12- } \\
\text { Oktadekadienoat }\end{array}$ & $5,49 \pm 0,42$ & $\begin{array}{c}10,84 \pm \\
1,31\end{array}$ & 0 & $\begin{array}{c}38,43 \pm \\
2,81\end{array}$ \\
\hline 7 & PUFA & $\begin{array}{l}\text { Asam 5,8,11,14- } \\
\text { eikosatetraenoat }\end{array}$ & $2,05 \pm 0,14$ & $\begin{array}{c}1,94 \pm \\
0,07\end{array}$ & 0 & 0 \\
\hline 8 & PUFA & $\begin{array}{l}\text { Asam cis } 5,8,11,14,17- \\
\text { eikosapentaenoat }\end{array}$ & $6,68 \pm 0,59$ & $\begin{array}{l}2,54 \pm \\
0,495\end{array}$ & 0 & 0 \\
\hline 9 & PUFA & $\begin{array}{l}\text { Asam } 8,11,14- \\
\text { eikosatrienoat }\end{array}$ & 0 & $\begin{array}{c}0,81 \pm \\
0,02\end{array}$ & 0 & 0 \\
\hline 10 & PUFA & $\begin{array}{l}\text { Asam 4,7,10,13,16,19- } \\
\text { Dokosaheksaenoat }\end{array}$ & $4,22 \pm 0,89$ & 0 & 0 & 0 \\
\hline 11 & PUFA & $\begin{array}{l}\text { Asam 4,7,10,13,16- } \\
\text { Dokosapentaenoat }\end{array}$ & 0 & $\begin{array}{c}2,28 \pm \\
0,13 \\
\end{array}$ & 0 & 0 \\
\hline 12 & PUFA & $\begin{array}{l}\text { Asam cis } 7,10,13,16- \\
\text { Dokosatetraenoat }\end{array}$ & $\begin{array}{c}0,71 \pm \\
0,001 \\
\end{array}$ & 0 & 0 & 0 \\
\hline 13 & SFA & Asam pentadekanoat & $4,27 \pm 0,22$ & $\begin{array}{c}1,86 \pm \\
0,09\end{array}$ & 0 & 0 \\
\hline
\end{tabular}




\begin{tabular}{lllcccc}
\hline \multirow{2}{*}{14} & SFA & Asam heksadekanoat & $\begin{array}{c}22,31 \pm \\
4,24\end{array}$ & $\begin{array}{c}27,21 \pm \\
1,4\end{array}$ & $41,66 \pm 2,36$ & $\begin{array}{c}20,49 \pm \\
1,3\end{array}$ \\
\hline 15 & SFA & Asam heptadekanoat & $2,86 \pm 0,04$ & 0 & 0 & 0 \\
\hline 16 & \multirow{2}{*}{ SFA } & Asam Oktadekanoat & $5,92 \pm 0,43$ & $\begin{array}{c}9,05 \pm \\
0,09\end{array}$ & 0 & $\begin{array}{c}13,62 \pm \\
0,43\end{array}$ \\
\hline 17 & - & Cholest-5-ene, 3-metoksi & 0 & 0 & $4,21 \pm 0,45$ & 0 \\
\hline 18 & - & Cholesta-3,5-diene & 0 & 0 & $13,84 \pm 1,37$ & 0 \\
\hline 19 & - & Tidak teridentifikasi & $\begin{array}{c}13,94 \pm \\
0,86\end{array}$ & $\begin{array}{c}6,8 \pm \\
0,42\end{array}$ & 0 & 0 \\
\hline
\end{tabular}

\subsection{Profil Asam Lemak}

Berdasarkan grafik pada gambar 1 , asam lemak jenuh (SFA) rata - rata paling mendominasi pada setiap minyak ikan dibandingkan dengan MUFA dan PUFA. Minyak ikan gurame diketahui paling banyak mengandung SFA yaitu sebesar
$41,65 \pm 2,35 \%$. Disamping itu, minyak ikan gurami juga kaya akan asam lemak MUFA yaitu sebanyak 40,29 $\pm 1,13 \%$, namun berdasarkan data grafik pada gambar 1 memperlihatkan bahwa minyak ikan gurame tidak mengandung PUFA.

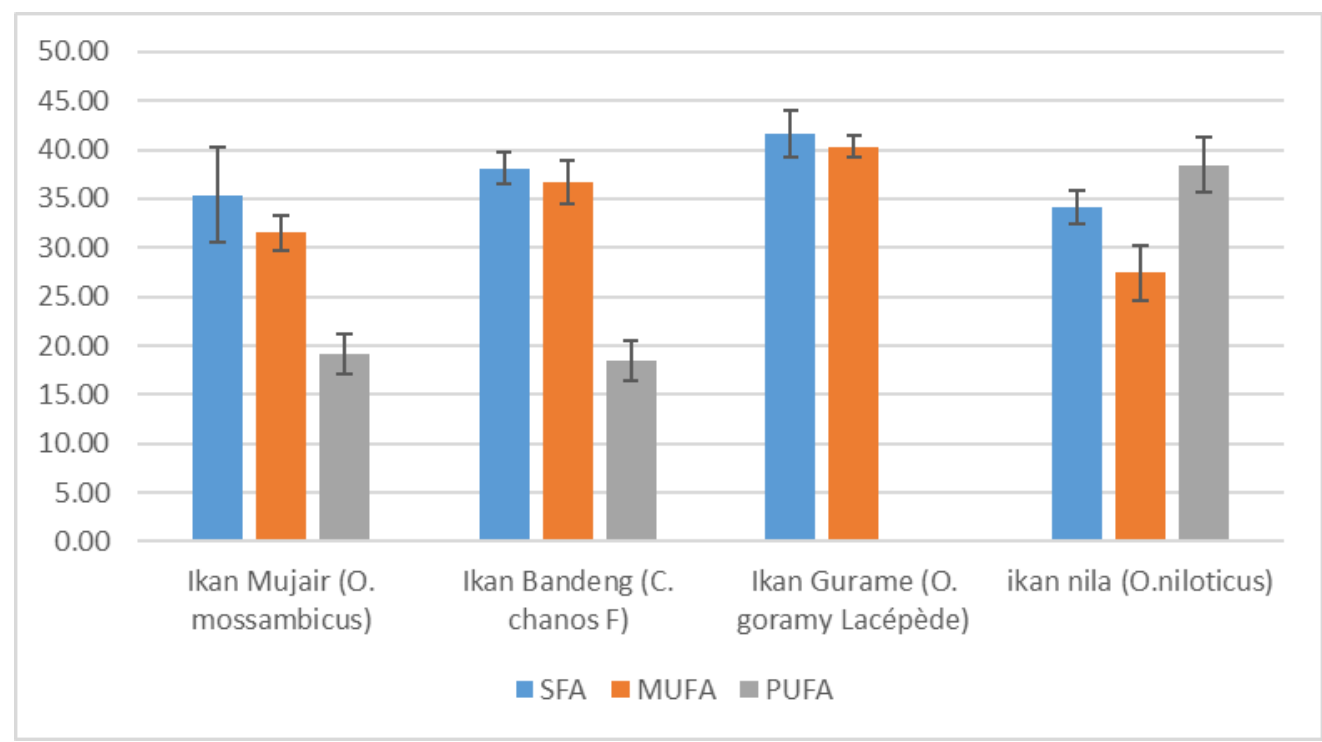

Gambar 1. Kandungan golongan asam lemak dari tiga jenis minyak ikan air tawar

Minyak ikan nila memiliki profil yang berbeda dibandingkan tiga minyak lainnya. PUFA pada minyak ikan nila sangat mendominasi jika dibandingkan dengan kelompok asam lemak lainnya. Kandungan PUFA pada ikan nila adalah sebesar $38,43 \pm 2,81 \%$. Hal ini berbeda jauh jika kita membandingkannya dengan profil ketiga minyak ikan lainnya yang rata - rata didominasi oleh golongan SFA.

Ikan Mujaer dan Ikan Bandeng meskipun hidup pada daerah perairan yang 
berbeda, namun memiliki profil golongan asam lemak yang mirip. Kandungan SFA paling mendominasi pada kedua minyak ikan tersebut yaitu pada minyak ikan mujaer mengandung 35,36 \pm 4,86\% dan minyak ikan bandeng sebesar 38,12 $\pm 1,58$ $\%$. Disamping itu, kandungan PUFA pada kedua ikan ini juga lebih rendah dibandingkan dengan golongan asam lemak lainnya yaitu minyak ikan mujaer sebesar $19,15 \pm 2,05 \%$ dan minyak ikan bandeng sebesar 18,41 $\pm 2,02 \%$. Adapun kandungan MUFA dalam minyak ikan mujaer adalah $31,55 \pm 1,79 \%$ dan minyak ikan bandeng $36,66 \pm 2,21 \%$. Hal ini perlu ditelaah lebih lanjut, apakah ada kesamaan sistem metabolisme serta sumber makanan yang dikonsumsi dari kedua ikan yang hidup di perairan berbeda ini. Data lengkap terkait level kandungan golongan asam lemak pada setiap minyak dapat dilihat pada gambar 1.

Berdasarkan data analisis KGSM (tabel 2 dan gambar 2), diketahui bahwa minyak ikan mujaer mengandung 5 jenis PUFA yaitu Asam 9,12-Oktadekadienoat (6), Asam 5,8,11,14-eikosatetraenoat (7), Asam cis 5,8,11,14,17-eikosapentaenoat (8), Asam $4,7,10,13,16,19-$ Dokosaheksaenoat (10), Asam cis7,10,13,16-Dokosatetraenoat (12). Minyak tersebut juga mengandung MUFA yang terdiri dari 2 jenis asam lemak dan SFA terdiri dari 4 jenis asam lemak.
Tabel 2 dan Gambar 2 juga membuktikan adanya kemiripan profil asam lemak antara minyak ikan mujaer dengan bandeng. Meskipun kandungan PUFA didalam kedua minyak ikan tersebut paling rendah dibandingkan golongan lainnya, namun kedua minyak ikan tersebut mengandung ARA, EPA dan DHA yang merupakan asam lemak esensial dan paling banyak mengandung manfaat.

Asam 5,8,11,14-eikosatetraenoat atau dikenal dengan nama asam arakhidonat (ARA) dan Asam 4,7,10,13,16,19-Dokosaheksaenoat (DHA), merupakan asam lemak esensial yang berdasarkan penelitian mampu menjaga dan mempertahankan fungsi kerja otak dan sistem kardiovaskular (Kiso, 2011). Asam cis-5,8,11,14,17eikosapentaenoat (EPA) telah dibuktikan memiliki dampak positif terhadap pasien penderita penyakit jantung koroner (Haris, 2004).

Secara lengkap, minyak ikan bandeng mengandung lima jenis PUFA meliputi Asam 9,12-Oktadekadienoat (6), Asam 5,8,11,14-eikosatetraenoat (7), Asam cis 5 ,8,11,14,17-eikosapentaenoat (8), Asam 8,11,14-eikosatrienoat (9), Asam 4,7,10,13,16-Dokosapentaenoat Minyak ikan bandeng juga mengandung MUFA yang terdiri dari Asam 9Heksadesenoat (1), asam Cis 10Heptadesenoat (2), Asam 11-oktadesenoat 
(3), Asam 9-Oktadesenoat (4), dan Asam cis-11-Eikosanoat (5). SFA yang terdapat minyak ikan bandeng diantaranya adalah asam pentadekanoat (13), asam heksadekanoat (14), dan asam oktadekanoat (16).

Minyak ikan gurame diketahui hanya mengandung dua golongan asam lemak yaitu golongan MUFA yaitu berupa asam 9-oktadesenoat (4) dan golongan SFA berupa asam heksadekanoat (14). Namun disamping itu, ikan gurame ternyata mengandung steroid yaitu 3-metoksi cholest-5-ene dan cholesta-3,5-diene.

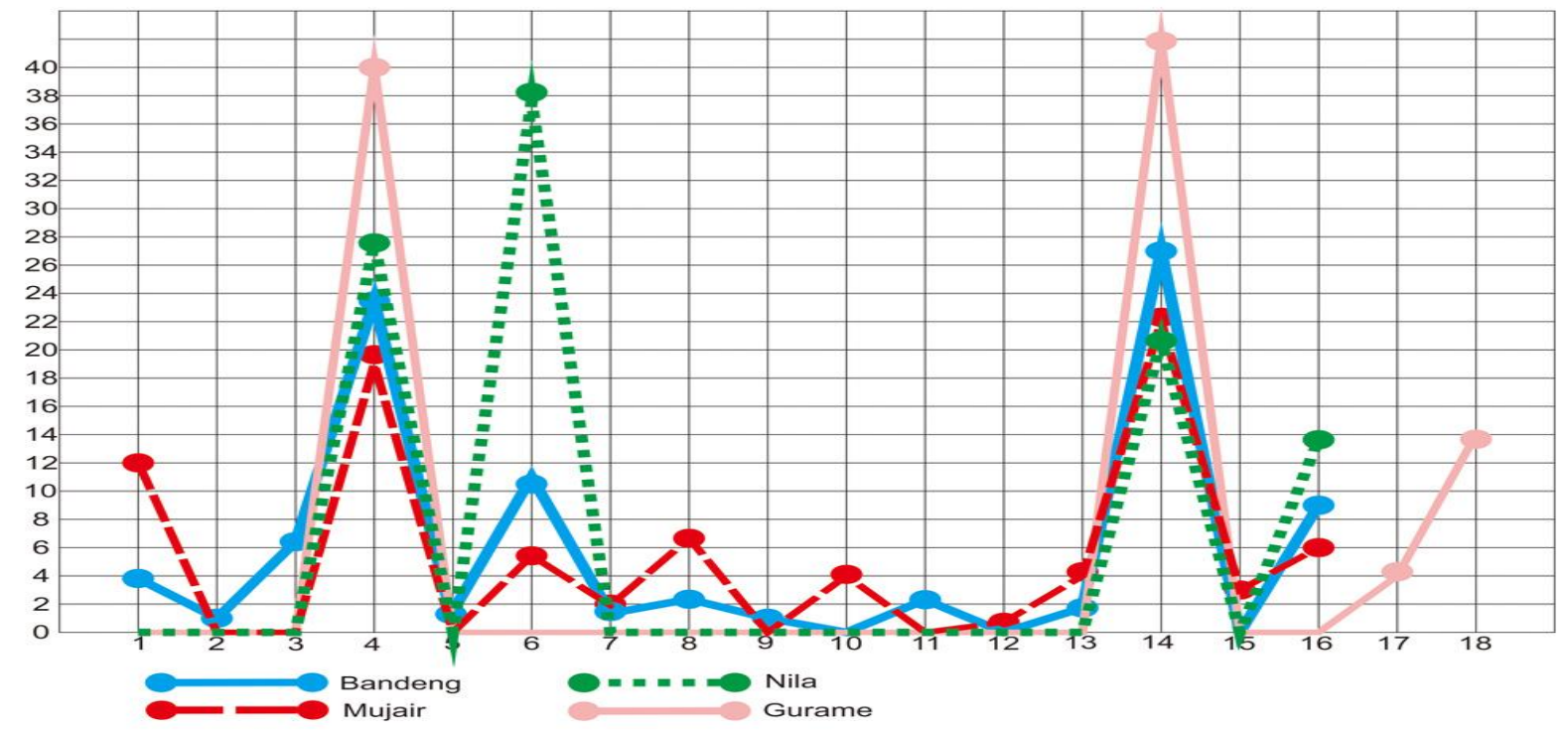

Gambar 2. Peta kandungan asam lemak dalam empat jenis minyak ikan air tawar.

Minyak ikan nila juga diketahui memiliki profil asam lemak yang hampir mirip dengan ikan gurame. Minyak ikan nila mengandung golongan MUFA berupa asam 9-oktadesenoat (4), golongan PUFA berupa asam 9,12-oktadekadietnoat (6), dan golongan SFA berupa asam heksadekanoat (14) dan asam oktadekanoat (16).

Asam 9-oktadesenoat atau dikenal sebagai asam oleat, jika dikombinasikan dengan asam laurat, dan asam miristat phenylephrine induced contraction yang merupakan faktor pemicu Benigh Prostatic
Hyperplasia (BHP) (Arruzazabala et al, 2011).

Dari uraian data diketahui meskipun ikan gurami, ikan nila dan ikan mujair sama - sama hidup di air tawar, namun ketiga ikan tersebut memiliki profil asam lemak yang sangat berbeda. Minyak ikan gurame merupakan satu - satunya minyak yang mengandung kolesterol. Minyak ikan nila diketahui memiliki profil yang hampir mirip dengan gurame, perbedaannya hanya pada kandungan asam lemak PUFA dan kolesterolnynya saja. Baik ikan gurame 
maupun ikan nila keduanya menghasilkan minyak yang mengandung lebih sedikit varian asam lemak dibandingkan dengan ikan mujair dan bandeng. Hal ini kemungkinan besar disebabkan karena pengaruh pakan yang diberikan di lokasi budidaya (Hussain et al., 2014).

Ikan bandeng yang hidup di air laut dan payau menghasilkan minyak dengan profil asam lemak yang hampir mirip dengan ikan mujair yang hidup di air tawar. Minyak yang terkandung didalam kedua ikan tersebut juga sama-sama mengandung omega-3 yaitu EPA. Hal ini menimbulkan pertanyaan menarik yang perlu dilakukan pembuktian lebih lanjut terkait kesamaan pola metabolisme serta sumber makanan yang dikonsumsinya. Seperti diketahui sebelumnya bahwa, ikan pada dasarnya tidak dapat memproduksi EPA dan DHA. Kedua asam lemak bermanfaat tersebut bersumber dari plankton yang dikonsumsi oleh ikan (Haris, 2004).

\section{KESIMPULAN}

Berdasarkan data analisis asam lemak yang diperoleh, ikan mujair mengandung minyak ikan paling besar yaitu 8,57 $\pm 0,06$ $\%$ dari total bahan kering yang digunakan tanpa kepala dan ekor. Ikan nila meskipun satu genus dengan mujaer ternyata mengandung minyak ikan paling rendah yaitu sebesar 0,28 $\pm 0,09 \%$. Berdasarkan penggolongan asam lemak, Minyak ikan mujaer mengandung SFA 35,36 $\pm 4,86 \%$,
MUFA $31,55 \pm 1,79 \%$, PUFA 19,15 $\pm 2,05$ $\%$. Minyak ikan bandeng mengandung SFA $38,12 \pm 4,86 \%$, MUFA 36,64 $\pm 2,21 \%$, PUFA $18,4 \pm 2,02$. Minyak Ikan gurami mengandung SFA 41,65 $\pm 2,35 \%$, MUFA $40,29 \pm 1,13 \%$. Minyak Ikan Nila mengandung SFA sebesar 34,11 $\pm 1,73 \%$, MUFA sebesar 27,47 $\pm 2,11 \%$, dan PUFA sebesar 38,43 $\pm 2,81 \%$. Minyak ikan mujair dan bandeng merupakan minyak yang mengandung EPA dan DHA. Kandungan EPA pada minyak ikan mujaer yaitu $6,68 \pm$ $0,59 \%$ dan DHA 4,22 $\pm 0,89 \%$. Pada ikan bandeng, EPA 2,54 $\pm 0,49 \%$.

\section{DAFTAR PUSTAKA}

Arruzazabala ML, Perez Y, Ravelo Y, Molina V, Carbajal D, Mas R, and Rodriguez E. 2011. Effect of oleic, lauric and myristic acids on phenylephrine-induced contactions of isolated rat vas deferens. Indian Journal of Experimental Biology 49: 684-688

Bockisch M. 1998. Fats And Oils Handbook, AOCS Press Hamburg Gemany. pp 31

Cahyono B. 2004. Budidaya Ikan Air Tawar, Kanisius, Yogyakarta. pp 21-23

Genisa AS. 2003. Sebaran dan Struktur Komunitas Ikan di Sekitar Estuaria Digul, Irian Jaya. Jurnal Ilmu Kelautan dan Perikanan 13(1): 01 09

Hanafiah A, Karyadi D, Lukiato W. Muhilal, Supari F. 2007. Desirable intakes of polyunsaturated fatty acids in Indonesian adults. Asia Pac J Clin Nutr 16(4): 632 - 638

Haris WS. 2004. Review : Fish oil Supplementation: Evidence For 
Health Benefits. Cleveland Clinic Journal of Medicine 71(3): 208-219

Homayooni B., Sahari MA. and Barzegar M, 2014 Concentrations of omega-3 fatty acids from rainbow sardine fish oil by various methods, International Food Research Journal 21(2):743-748

Hussain B., Sultana T., Sultana S., Jabeen F., Nadeem S., and Mahboob S., 2014. Habitat related variations in omega series of unsaturated fatty acids in Indian major Carp Cirrhinus mrigala, Pure Appl. Bio., 3(4):192-198,

Kiso Y. 2011. Effects of arachidonic acid and docosahexaenoic acid on the agerelated decline in brain and cardiovascular system function. $J$. Pharmacol Sci 115:471-475

Khosroshahi HT, Houshyar J, Tabrizi A, Vatankhah AM, Zonouz NR, Hesari RD. 2010. Effect of omega-3 fatty acid on oxidative stress in patients on hemodialysis. Iranian Journal of Kidney Diseases 4(4): 322-326

Leger T., AzarnoushK., Traoré A., Cassagnes L., Rigaudière J., Jouve C., Pagès G., Bouvier D., Sapin V., Pereira B., Bonny J., and Demaison L., 2019. Antioxidant and Cardioprotective Effects of EPA on Early Low-Severity Sepsis through UCP3 and SIRT3 Upholding of the Mitochondrial Redox Potential, Oxidative Medicine and Cellular Longevity, 2019
Maulana IT, Sukraso, Damayanti S. 2014. Telaah kandungan asam lemak dalam minyak ikan indonesia. Jurnal Ilmu dan Teknologi Kelautan Tropis 6(1):121-130

Murtidjo, 2001. Beberapa Metode Pembenihan Ikan Air Tawar. Kanisius (anggota IKAPI), Yogyakarta: pp 57

Olaitan BP, Chen I-Ping, Norris J, Feinn R. Oluwatosin OM, and Reichenberger EJ. 2011, Inhibitory activities of omega-3 fatty acids and traditional african remedies on keloid fibroblasts. Wound 23(4): 97 - 105

Saito M \& Kubo K. 2003. Relationship between tissue lipid peroxidation and peroxidizability index after $\alpha$ linolenic, eicosapentaenoic, or docosahexaenoic acid intake in rats. British Journal of Nutrition 89:19-28

Susanto H. 2014. Budidaya 25 Ikan di Pekarangan, Penebar Swadaya, Jakarta. pp 19-27

Tangwatcharin P and Khopaibool P, 2012, Activity of Virgin Coconut Oil, lauric acid or monolaurin in combination with lactic acid against staphylococcus aureus, Southeast Asian Journal of Tropical Medicine and Public Health 43(4):969.

Weimann E, Silva MBB, Murata GM, Bortolon JR, Dermargos A, Curi R, et al. 2018 Topical anti-inflammatory activity of palmitoleic acid improves wound healing. PLOS ONE 13(10):e0205338. 